\title{
Disaggregases, molecular chaperones that resolubilize protein aggregates
}

\author{
DAVID Z. MOKRY ${ }^{1}$, JOSIELLE ABRAHÃ $O^{1,2}$ and CARLOS H.I. RAMOS ${ }^{1}$ \\ ${ }^{1}$ Instituto de Química, Universidade Estadual de Campinas/UNICAMP, \\ Rua Josué de Castro, s/n, Caixa Postal 6154, 13083-970 Campinas, SP, Brasil \\ ${ }^{2}$ Instituto de Biologia, Universidade Estadual de Campinas/UNICAMP, \\ Rua Monteiro Lobato, s/n, Caixa Postal 6109, 13083-970 Campinas, SP, Brasil \\ Manuscript received on December 8, 2014; accepted for publication on February 2, 2015
}

\begin{abstract}
The process of folding is a seminal event in the life of a protein, as it is essential for proper protein function and therefore cell physiology. Inappropriate folding, or misfolding, can not only lead to loss of function, but also to the formation of protein aggregates, an insoluble association of polypeptides that harm cell physiology, either by themselves or in the process of formation. Several biological processes have evolved to prevent and eliminate the existence of non-functional and amyloidogenic aggregates, as they are associated with several human pathologies. Molecular chaperones and heat shock proteins are specialized in controlling the quality of the proteins in the cell, specifically by aiding proper folding, and dissolution and clearance of already formed protein aggregates. The latter is a function of disaggregases, mainly represented by the $\mathrm{ClpB} / \mathrm{Hsp} 104$ subfamily of molecular chaperones, that are ubiquitous in all organisms but, surprisingly, have no orthologs in the cytosol of metazoan cells. This review aims to describe the characteristics of disaggregases and to discuss the function of yeast Hsp104, a disaggregase that is also involved in prion propagation and inheritance.
\end{abstract}

Key words: amyloid, disaggregase, heat shock protein, molecular chaperones, prion, protein folding.

\section{INTRODUCTION}

\section{PROTEIN FOLDING AND MISFOLDING}

Protein folding is considered to be the second half of a gene expression 'game' (Gierasch and King 1990) because, in general, the proper function of a protein is reached when it adopts its native structure from the unfolded state (Ramos and Ferreira 2005, Dill and MacCallum 2012, Baldwin and Rose 2013). Following this perspective, the

Correspondence to: Carlos H.I. Ramos

E-mail: cramos@iqm.unicamp.br unfolded state is a large ensemble of conformations that folds to a stable conformation or native state, which is generally considered to comprise a unique conformation (Ramos and Ferreira 2005, Dill and MacCallum 2012, Baldwin and Rose 2013). During folding the polypeptide chain can adopt several transient intermediate conformations before reaching a stable and lower favorable free energy level, sometimes referred to as a "valley" or "trough" in free energy, to complete folding. The resulting native protein structure corresponds to a unique biologically-active state, for which it has 
been evolutionarily selected. However, especially inside the cell, the folding process is not without complications, and misfolding can not only cause loss of function, but also lead to aggregation (Finka and Goloubinoff 2013). This does not occur without biological consequences, since misfolded proteins and protein aggregation are strongly correlated with disease.

Aggregates are soluble or insoluble nonphysiological associations of misfolded proteins via exposed hydrophobic regions (for reviews see Doyle et al. 2013, Knowles et al. 2014). Polypeptides can misfold into disordered or organized aggregates, one example of the latter being amyloids, that share a typical morphology (long, unbranched and often twisted structures with a few nanometers in diameter) where the core structure is composed of $\beta$-sheets whose strands run perpendicular to the fibril axis (Sunde and Blake 1997, Dobson 2004, Chiti and Dobson 2006). Some disordered aggregates and all amyloids are in a lower free energy state than the intended native form of the protein, rendering them incredibly stable. Furthermore, amyloid-like fibrils have other unique properties, such as being recognized by particular dyes and conformational specific antibodies (Vitrenko et al. 2007), and resistance to certain proteases and ionic detergent solubilization. These properties significantly prevent the solubilization and clearance of amyloids both in vivo and in vitro.

The formation of amyloid-like fibrils by damaged proteins is a characteristic of several neurodegenerative diseases, such as Huntington's, Parkinson's, Alzheimer's, and prion related diseases (Ramos and Ferreira 2005, Chiti and Dobson 2006, Eisenberg and Jucker 2012). There are currently no effective treatments against these diseases, and their occurrence is strongly correlated with age due to progressive failure in the Protein Quality Control (PQC) system (see below) and because amyloids, like prions, can template further amyloid formation when in contact with soluble proteins. Such mechanisms in which direct phenotype inheritance is caused by changes in protein folding that are amyloidogenic in nature, also known as non-Mendelian inheritance, are explained by the prion hypothesis (Chien et al. 2004, Tuite and Serio 2010). In order for prion propagation to occur, a series of minimal requirements are needed. First, soluble polypeptides must become incorporated into prion complexes that have to be maintained. Secondly, prion complexes must seed new prion complexes, and lastly, prions have to be inherited by daughter cells, or transiently established into neighboring cells, and continue to propagate in the new cells. Inhibition of any of these steps results in prion loss or 'curing'.

However, it is important to point out that it is still controversial whether amyloid formation is cytotoxic or cytoprotective. A current hypothesis is that pre-amyloidogenic forms are the cytotoxic species and amyloid aggregates are innocuous (Arrasate et al. 2004, Shorter and Lindquist 2005, Cheng et al. 2007, Piccardo et al. 2007). For instance, melanin synthesis in humans is an example of functional amyloid-like structures working in a beneficial way (Fowler et al. 2006). Moreover, yeast prions are examples of non-cytotoxic aggregates under native protein expression conditions, and several studies have demonstrated that some yeast prions could be biologically beneficial (Lindquist 1997), explained in more detail below. In any case, as discussed above, and elaborated upon further below in the context of prions, amyloidlike aggregates have the ability to template more aggregates when in contact with soluble proteins.

MOLECULAR CHAPERONES: HOLDERS,

FOLDASES AND DISAGGREGASES

In order to facilitate the correct folding, and prevent misfolding and aggregation, cells have evolved a complex quality control system formed by proteins known as heat shock proteins and molecular chaperones (for reviews see Douglas et al. 2009, Hartl et al. 2011, Tiroli-Cepeda and Ramos 2011, Kim et al. 2013, Priya et al. 2013). Chaperones exist in every cell and cell compartment and have a 
key role in protein homeostasis and stress situations (Douglas et al. 2009, Hartl et al. 2011, Tiroli-Cepeda and Ramos 2011, Kim et al. 2013, Priya et al. 2013). These proteins can be understood and classified by the way they interact with substrates. By this classification, three general types of chaperones exist, referred to as holders (we use 'holder' instead of 'holdase' as the latter term implies an enzymatic activity which is not accurate, foldases, and disaggregases (Mayer 2010, Tiroli-Cepeda and Ramos 2011). Holders bind client proteins in an ATP-independent manner, named this way because they secure the client protein for further action by other chaperones, commonly a foldase, but can also independently protect against further protein misfolding or aggregation. Classical examples of holders are small Hsps (sHsps) and Hsp40s (TiroliCepeda and Ramos 2011). Foldases help the substrate adopt its native state in an ATP-dependent manner and are responsible for the major refolding activities in the chaperone system. Classical examples of foldases are chaperonin, Hsp70s and Hsp90s (Bukau and Horwich 1998, da Silva and Ramos 2012). Additionally, other chaperones and co-chaperones interact with foldases and modulate their respective activities in a dramatic way (Hartl et al. 2011, Tiroli-Cepeda and Ramos 2011, da Silva and Ramos 2012).

Despite their broad chaperone activities, holders and foldases are unable to completely prevent the formation of aggregates inside the cell, and independently contain no remodeling activity on the aggregates that do form (Doyle et al. 2013). For cell survival, the reactivation of aggregated proteins can be viewed as more important than the mere elimination of aggregates, considering the significant energy and temporal requirements for $d e$ novo protein synthesis. The reactivation activity is performed by a specific subclass of disaggregases within the Hsp100 family, named ClpB/Hsp104, that have the remarkable ability to extricate protein monomers from aggregates in an ATP-dependent manner (Zolkiewski et al. 2012, Doyle et al. 2013). Additionally, all three of the chaperone activities described are intrinsically linked to each other. For example, the activities of many foldases are modulated by interactions with holders (Fan et al. 2003, Summers et al. 2009a). Holders and foldases are unable to bind proteins within aggregates, so they rely on disaggregases to liberate protein clients from aggregates (Zolkiewski et al. 2012, Doyle et al. 2013). However, the $\mathrm{ClpB} / \mathrm{Hsp} 104$ subfamily is not able to recover and refold the majority of protein substrates without the cooperation of the Hsp70 system, and this cooperation is highly specific, since disaggregation is contingent on the presence of Hsp70 and Hsp100 from the same, or highly related, species (Glover and Lindquist 1998). Collectively, the cooperation of holders, foldases, and disaggregases is necessary to maintain a cellular environment free of potentially toxic aggregates (Fig. 1).

Together with the proteostatic system, chaperones and Hsps form a PQC network that protects cells against misfolding and aggregation (Douglas et al. 2009, Tiroli-Cepeda and Ramos 2011). Most of the members of this network are constitutively expressed, but their expression levels are considerably increased as a response to stress conditions. In a clever mechanism, many Hsps bind to the transcription factor that induces their own expression, HSF (heat shock factor), in the cytoplasm. This decreases the free cellular concentration of HSF, which in turn decreases HSF translocation to the nucleus, and subsequently reduces expression of Hsps (for a review see Morimoto 2011). The increase in misfolded proteins in the cytosol decreases the affinity of the Hsp/HSF complex, thereby freeing HSF for nuclear translocation. Unfortunately, the degree of the protective effect of the PQC network decreases with aging, mainly due to overloading and cellular damage throughout the years, allowing the formation of disordered aggregates and amyloids, which further aggravates cellular deterioration.

Abbreviations: HSF, heat shock factor; Hsp, heat shock protein; PD, Parkinson's Disease; PQC, protein quality control. 

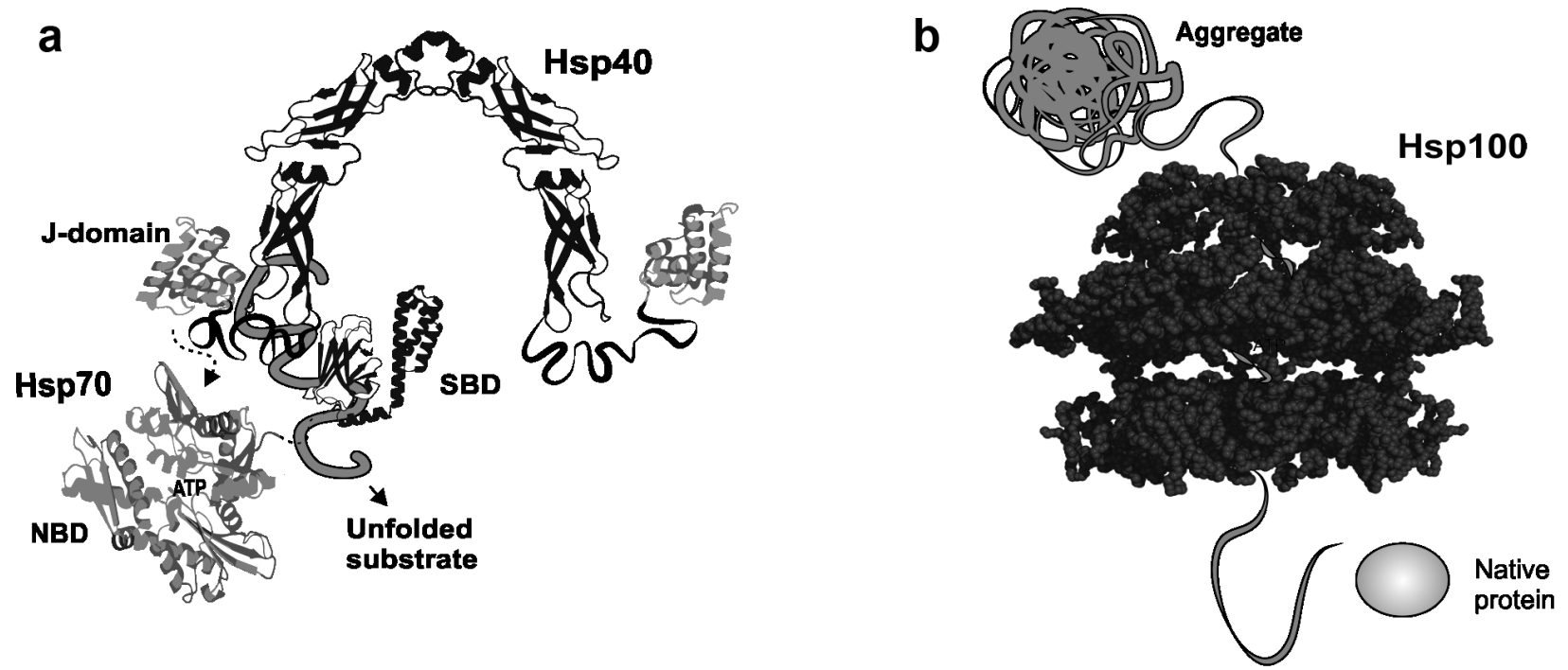

Figure 1 - Molecular chaperones and heat shock proteins can be classified by their interaction with substrates. a) Holders bind client proteins in an ATP-independent manner, named this way because they secure the client protein for further action by other chaperones, commonly a foldase, that coaxes the substrate into its native state in an ATP-dependent manner. In this figure, the holder is represented by an Hsp40 (PDB accession number 1C3G) that delivers a client protein (unfolded substrate) to the NBD of Hsp70 (PDB accession number 1HJO) (modified from Borges et al. 2012); SBD: substrate binding domain from Hsp70. b) Disaggregases have the remarkable ability to extricate protein monomers from aggregates in an ATP-dependent manner.

\section{ClpB/Hsp104, A SUBFAMILY OF Hsp100}

Chaperones that have disaggregase function are primarily classified within the $\mathrm{ClpB} / \mathrm{Hsp} 104$ protein subfamily of Hsp100s, and are all a subset of the AAA+ (ATPases Associated with various cellular Activities) superfamily of ATPases, a diverse class of proteins that provides a variety of other functions, including intracellular trafficking, cell cycle regulation, DNA replication, and protein degradation, among others (for reviews see Patel and Latterich 1998, Sauer et al. 2004, Snider and Houry 2008, Zolkiewski et al. 2012). Even though $\mathrm{ClpB} / \mathrm{Hsp} 104 \mathrm{~s}$ are not essential under non-stress conditions, they confer protective qualities against various forms of stress, and have the remarkable ability to both resolubilize and reactivate aggregated proteins.

All members within the Hsp100 family, including ClpB and Hsp104, share several features, with some important differences. For example, all have an N-terminal Domain (NTD) that contributes to the high-binding affinity that Hsp100s have for aggregates, although the presence of the NTD is not an absolute requirement for thermotolerance (Beinker et al. 2002, Mogk et al. 2003, Barnett et al. 2005). Furthermore, the Hsp100 family may be divided into two classes, based on the presence of two (Class I) or one (Class II) nucleotide binding domains (NBDs). Each NBD contains canonical Walker A and B motifs and sensor-1, and -2 motifs, which are important components in ATP binding and hydrolysis. The Hsp100 classes can be further divided according to the presence of a coiled-coil middle, or M domain, integrated within the first nucleotide binding domain. Although this domain is dispensable for the ATPase and protein translocating activities of unfolded substrates (Sielaff and Tsai 2010, Desantis and Shorter 2012), it is essential for reactivating protein aggregates. Specifically, this domain is composed of four antiparallel helices that are located on the outer surface and is flexible, moving in response to nucleotide binding as it participates in substrate interaction (Fig. 2; Lee et al. 2003, Schirmer et al. 2004). 
a

b


Figure 2 - ClpB/Hsp104. a) Schematic representation of the domains and motifs in Hsp100 proteins from the ClpB/Hsp104 subfamily. Domains from N- to C-terminal: N-terminal, NBD1, Walker A, Walker B, Sensor-1, arginine fingers, M-domain, NBD2, Sensor-2 and C-terminal. b) Amino acid alignment of Escherichia coli ClpB and Saccharomyces cereviseae Hsp104. Gray patterns are the same as in A) (modified from Lee et al. 2003 and Shirmer et al. 2004).

The mobility of the M-domain is critical for the disaggregase function of ClpB (Lee et al. 2003) and Hsp70 has a role in shifting the M-domain away from the NBD1 that increases both the ATPase activity and the disaggregase activity of Hsp100 (Oguchi et al. 2012, Lipińska et al. 2013). Additionally, some mutations in the $\mathrm{M}$ domain of Hsp104 can potentiate its disaggregase and ATPase activities (Jackrel et al. 2014).

Studies with Hsp104 have shown that the C-terminal region located after the second NBD is involved in oligomerization and co-chaperone interaction (Mackay et al. 2008). Orthologs of the Class I subfamily with an M-domain exist in bacteria (ClpB), yeast (Hsp104), and plants (Hsp101) (Lee et al. 1994, Queitsch et al. 2000, Cagliari et al. 2011), all of which are heat-induced and implicated in protein unfolding/disaggregation and degradation (Schirmer et al. 1996, Glover and Lindquist 1998, Dougan et al. 2002, Hodson et al. 2012, Winkler et al. 2012a). Surprisingly, metazoans lack a bona fide ClpB/Hsp100-like disaggregase in their cytosol (see below). 
All Hsp100s self-assembly into ring-shaped structures and conformational changes are triggered by ATP binding and hydrolysis, which changes the positions of bound substrates relative to each other, followed by the translocation of the polypeptide through the central channel during aggregate reactivation (Weibezahn et al. 2004, Zolkiewski 2006). By using E. coli $\mathrm{ClpB}$ as a model, Schlieker et al. (2004) showed that the disaggregation mechanism involves continuous extraction of unfolded proteins from the aggregate that are solubilized into the central channel in a process called "threading". Likewise, the hexameric structure of ClpB from Thermus thermophilus (Fig. 1b) is crucial for its activity because it provides multiple sites for polypeptide substrate binding, which are translocated through its central channel during aggregate reactivation (Schirmer et al. 1996, Lee et al. 2003, Schlieker et al. 2004, Weibezahn et al. 2004, Zolkiewski 2006, Barends et al. 2010, Mayer 2010, Zolkiewski et al. 2012, Doyle et al. 2013). The solubilized protein can then be refolded either spontaneously, or by a chaperone network independent of $\mathrm{ClpB}$. It is important to emphasize that the extricated monomer, if not immediately refolded, could potentially reaggregate, especially in the presence of aggregate "seeds", and thus overexpression of an Hsp 100 could hypothetically increase the amount of aggregates. However, the resulting aggregate may be different and less toxic than the initial form, and in fact overexpression of some chaperones increases the amount of insoluble aggregates, which correlates with suppression of aggregate cytotoxicity (Douglas et al. 2008, Wolfe et al. 2014). Likewise, heterologous expression of an Hsp100 could increase aggregates, due to the absence of a native Hsp70/40 system with which to cooperate.

Although not a requirement, the presence of an Hsp70/40 system greatly enhances the ability of Hsp100 to bind and reactivate aggregates, suggesting the two systems may physically interact. Despite this, a stable complex between Hsp100 and Hsp70 has not been observed to date, yet several lines of evidence exist that strongly support an interaction. First, as stated, Hsp100 requires a synergistic interaction with Hsp70 and Hsp40 molecular chaperones to completely recover functional proteins from the majority of aggregates (Glover and Lindquist 1998, Goloubinoff et al. 1999, Mogk et al. 1999). Secondly, there is kinetic evidence that suggests the interaction between Hsp70/DnaK with the aggregated substrate is the rate-limiting step of disaggregation. In addition, it has been well corroborated that the interaction between $\mathrm{ClpB} / \mathrm{Hsp} 104$ and Hsp70 forms a bichaperone system that is species-specific (Zietkiewicz et al. 2004, 2006, Glover and Lindquist 1998, Schlee et al. 2004, Miot et al. 2011). For example, experiments have demonstrated that the replacement of the M-domain of yeast Hsp104 with that of bacterial $\mathrm{ClpB}$ is sufficient to exchange the species specificity, allowing the yeast Hsp104 chimera to cooperate with the bacterial Hsp70 system in protein disaggregation and vice versa (Sielaff and Tsai 2010). These authors further demonstrated that the M-domain controls Hsp104 function through direct interaction with the cognate Hsp70 system which is required to unleash the Hsp104 protein remodeling activity. As a final piece of evidence, both $\mathrm{ClpB}$ and Hsp104 require their Hsp70 counterparts for binding to some heatdenatured aggregates and prion fibrils (Winkler et al. 2012b) (see below).

In order to better understand the dynamics of protein disaggregation in the context of Hsp70 and Hsp40, we here provide a model for the cooperation between these proteins (Doyle et al. 2013) (Fig. 3). First, Hsp40, a holder, interacts with the aggregate and delivers it to the Hsp70 foldase. Hsp70 then interacts with the surface of the aggregate by remodeling it to free exposed unstructured hydrophobic regions. Hsp 104, a disaggregase, is then recruited by the Hsp70/aggregate complex and initiates the extraction of protein monomers from the aggregate by ATP coupled translocation through its central pore. This ATPase activity is stimulated by interactions involving the M-domain with 


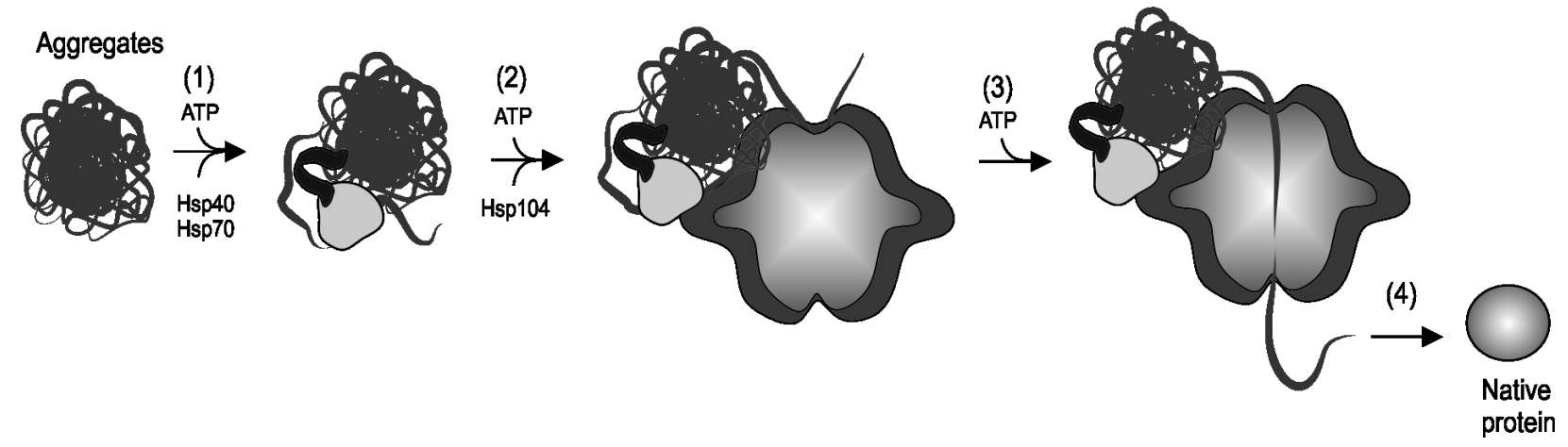

Figure 3 - A model for the cooperation between Hsp104, Hsp70 and Hsp40 to resolubilize aggregates. The chaperone system (Hsp40 and Hsp70, represented by black and light gray, respectively) identifies and associates with aggregates (1), from which Hsp104 can then interact directly through a small region of the Hsp104 M-domain (2), promoting interaction of Hsp104 with the aggregate. The sum of these interactions causes transmission of signals through the M-domain to NBD1, thereby coupling ATP hydrolysis to stimulate disaggregase activity by translocation through the central pore of Hsp104 (3). Following this, the unfolded polypeptide is released from Hsp104 and may spontaneously refold or is refolded to native protein with the assistance of other cellular chaperones (4) (modified from Miot et al. 2011).

Hsp70. The unfolded polypeptide is subsequently released to refold either spontaneously, or with the aid of other chaperone machines.

\section{YEAST Hsp104, A MOLECULAR CHAPERONE INVOLVED IN THE RECOVERY OF AGGREGATES AND PRION PROPAGATION AND INHERITANCE}

One of the most studied Hsp100s is the Class I disaggregase from yeast (Hsp104) which, like all Hsp100s, plays a major role in the modification and dissolution of heat denatured protein aggregates (Parsell et al. 1994, Glover and Lindquist 1998, Bösl et al. 2006, Doyle et al. 2013). This protein was identified more than 20 years ago as a stress-induced chaperone vital for tolerance to heat and ethanol stresses, as well as to some heavy metals (Sanchez and Lindquist 1990, Parsell et al. 1991, Lindquist and Kim 1996), and seems to have a quaternary structure with subtle differences (Fig. 4) compared to T. termophilus ClpB (Wendler and Saibil 2010). Yeast knockouts of the $h s p 104$ gene are viable, but have 100-1000-fold more mortality at $50{ }^{\circ} \mathrm{C}$ than wild-type, whereas knockouts transformed with the hsp 104 gene recover thermotolerance (Sanchez and Lindquist 1990, Sanchez et al. 1992, Parsell et al. 1994). Additionally, Hsp104 is involved in replicative cell aging in yeast, specifically by being involved in the asymmetric segregation (and retention) of damaged carbonylated proteins in the progenitor cell. This ensures cellular juvenescence in the daughter cells by preventing inheritance of damaged and nonfunctional proteins in the progeny (Erjavec et al. 2007).

Although purified Hsp104 is not capable of protecting luciferase against in vitro aggregation, it cooperates with Hsp70/Ssa1 and Hsp40/Ydj1 in a system that rescues and refolds protein aggregates even in vitro (Glover and Lindquist 1998), demonstrating that the chaperone is effective in dissociating already formed aggregates. Hsp104 appears to be capable of functioning properly even under severe stress conditions, since it retains ATPase activity in low salt concentrations, high temperatures, and high concentrations of ethanol (Schirmer et al. 1998). In fact, Hsp104 has a remarkable degree of operational plasticity compared to bacterial Hsp100 (ClpB). For example, it employs radically different mechanisms to remodel amyloid from disordered aggregates (see below), and can tolerate several defective subunits within the hexamer without undergoing a complete loss in activity (DeSantis et al. 2012). On the 


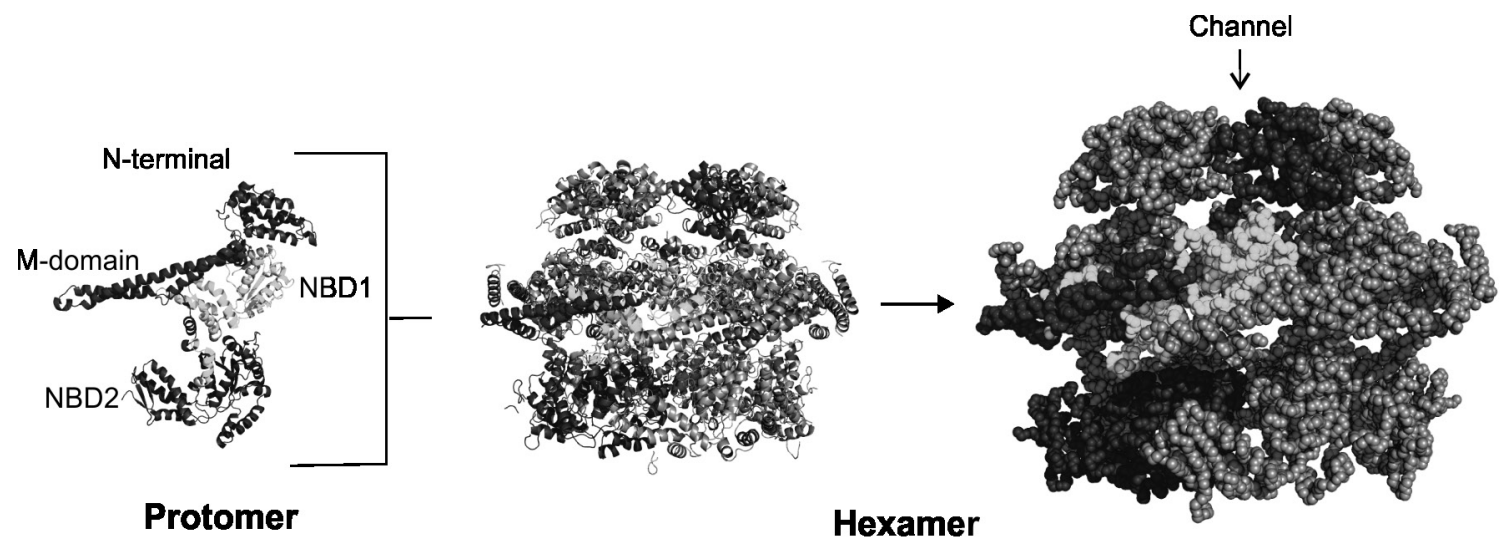

Figure 4 - Hexameric model for the Hsp100 family. Protomer cartoon representation of the structure of ClpB from Thermus thermophilus (PDB accession number 1QVR); hexamer cartoon and sphere representation (PDB accession number 4D2U) with detached protomer and the channel. Gray patterns in left are maintained: N-terminal, NBD1, M-domain and NBD2.

contrary, $\mathrm{ClpB}$ is relatively intolerant to defective subunits, and has limited activity against amyloid, albeit a higher ability to eliminate disordered aggregates compared to Hsp104 (DeSantis et al. 2012).

The function of Hsp104 is carefully choreographed by its two NBDs, which communicate with each other to coordinate its activity. Although they have low sequence homology to each other, both are required for thermotolerance, whereas NBD1 is involved in ATP hydrolysis and NBD2 is required for proper oligomerization, the reverse is true for bacterial ClpB and ClpA (Parsell et al. 1994, Singh and Maurizi 1994, Seol et al. 1995, Pak et al. 1999, Kim et al. 2000). Additionally, ADP is likely an inhibitor of the ATPase activity of Hsp104 (Kummer et al. 2013) although, like ATP, the nucleotide stimulates oligomerization (Parsell et al. 1994, Hattendorf and Lindquist 2002). During function, Hsp104 cycles between an ADP-bound state, which has low affinity for polypeptides, and an ATP-bound state, which has high affinity for polypeptides (Bösl et al. 2006). Doyle et al. (2007) reported that, even in the absence of other chaperones, a mixture of ATP and ATP-gamma-S, a slowly hydrolyzable nonphysiological ATP analogue, activates the resolubilization of aggregates by Hsp104. This activity is dependent on permissive ratios of ATP and ATP-gamma-S, since in the presence of ATP alone the activity is abolished. The reason for this is unclear, but likely due to ATP-gamma-S mimicking regulatory events in the Hsp104 machinery.

Although mammals lack an apparent Hsp104 ortholog, both yeast and mammals can carry prions, and Hsp104 is involved in yeast prion propagation and inheritance. Yeast prions resemble mammalian prions in their non-Mendelian inheritance and amyloid state (Chien et al. 2004, Inge-Vechtomov et al. 2007, Satpute-Krishnan et al. 2007, Tuite and Serio 2010) and are formed when soluble proteins are converted into an amyloid-like fibrilar structure and then act in the conversion of other soluble polypeptides into amyloids (Romanova and Chernoff 2009). All yeast prions identified to date are rich in glutamine and asparagine residues (Suzuki and Tanaka 2012). [PSI+] (Shorter and Lindquist 2004), [RNQ+] (also referred to as [PIN+]) (Sondheimer and Lindquist 2000), and [URE3+] (Masison and Wickner 1995, Moriyama et al. 2000), are the most studied yeast prions that are derived from native yeast proteins (Sup35p, Rnq1p, and Ure2p, respectively). Unlike mammalian prions, which are uniformly fatal, yeast prions are nonlethal when endogenously expressed under native conditions. Nonetheless, it is an open 
question whether yeast prions are a biological benefit, such as behaving as capacitors of evolution (Lindquist 1997) or a biological burden (for a review see Wickner et al. 2011). In any case, each prion behaves differently when overexpressed. For example, overexpression of [PSI + ] is toxic, not because of the aggregate itself, but because $[\mathrm{PSI}+]$ formation results in an inactive yet essential soluble translational termination factor from which it is derived (sup35) (Derkatch et al. 1997). On the other hand, $\left[\mathrm{RNQ}^{+}\right]$is toxic by its own nature (Douglas et al. 2008). In addition, both [PSI+] and [URE3+] prion strains induce the expression of Hsp104 and Hsp70, suggesting prion presence is stress inducing (Jung et al. 2000, Schwimmer and Masison 2002).

Counterintuitively, elimination or inhibition of Hsp104 'cures' the prion phenotype. (Chernoff et al. 1995, Wegrzyn et al. 2001). This is explained by the fact that Hsp104 acts by disassembling (seeding) amyloid fibers, thus generating more fibers that are transmitted to daughter cells during cell division (Collins et al. 2004, Tessarz et al. 2008). Prion severing is dependent on the ATPase activity of Hsp104, since its inhibition concomitantly inactivates the severing activity, curing prions by effectively serially diluting their cellular concentration during each mitotic division. This dilution creates "dead-end" aggregates (Wegrzyn et al. 2001). Likewise, the presence of small concentrations (1-5 mM) of guanidinium chloride $(\mathrm{Gdm}-\mathrm{Cl})$ can cure prions, since $\mathrm{Gdm}-\mathrm{Cl}$ acts as an inhibitor of Hsp104. Although the action of $\mathrm{Gdm}-\mathrm{Cl}$ is still not fully understood, its presence also decreases in vivo resolubilization of proteins and thermotolerance (Tuite et al. 1981, Ferreira et al. 2001) and it inhibits the ATPase activity of both Hsp104 and ClpB, but increases the ATPase activity of the latter while inhibiting the activity of the former (Grimminger et al. 2004, Nowicki et al. 2011, Kummer et al. 2013). This reversed effect could be explained by the functional inversion of the NBDs in Hsp104 and ClpB, previously described above. Curiously, $\mathrm{ClpB}$ is not capable of propagating $[\mathrm{PSI}+]$ in vivo, likely due to its inability to interact with the yeast Hsp70/Hsp40 system, and thereby demonstrating that the ability to remodel prions is not a global property of Hsp100s, and may even be prion specific (Tipton et al. 2008).

Sup35 (phenotype [psi']), as mentioned, is a soluble translational termination factor in yeast that aggregates into an insoluble prionic state known as $\left[\mathrm{PSI}^{+}\right]$, causing a reduction in the fidelity of translation termination, i.e. read through of stop codons, which is heritable (Paushkin et al. 1996, Uptain and Lindquist 2002). Where present and undisrupted, the [PSI+] phenotype continuously passes from generation to generation. $\left[\mathrm{PSI}^{+}\right]$is mediated via interactions at its $\mathrm{N}$-terminal, which is rich in glutamine and asparagine residues, and middle domains, which are sufficient when in an amyloidogenic form to induce prion conversion (Tanaka et al. 2004). As with all yeast prions, $\left[\mathrm{PSI}^{+}\right]$maintenance and inheritance is dependent on Hsp104, and overexpression of Hsp104 cures the $[\mathrm{PSI}+]$ prion, but not $[\mathrm{RNQ}+]$ or $[\mathrm{URE} 3+]$ (Wickner 1994). More specifically, the N-terminus of Hsp104 is essential for [PSI+] prion curing, while dispensable for prion propagation, and the middle domain of Hsp104 is important for [PSI+] prion shearing (Hung and Masison 2006, Dulle et al. 2014).

The conformational state of the Rnq1 protein, which has a prion domain at the C-terminus, determines the yeast prion $\left[\mathrm{RNQ}^{+}\right]$phenotype (Sondheimer and Lindquist 2000). The native function of Rnq1p is not clear, but the prion form interacts and helps other polypeptides, such as sup 35 and those with polyQ extensions, to form amyloidlike aggregates in a process called prion crossseeding (Osherovich and Weissman 2001, Meriin et al. 2002, Taneja et al. 2007). In fact, the presence of [RNQ+] induces de novo appearance of [PSI+] by several fold (Derkatch et al. 1997, Kurahashi et al. 2011). Interestingly, [RNQ+] seems to need less Hsp104 activity to maintain transmissible forms when compared to Sup35 (Bardill et al. 2009), and mutations in the M-domain of Hsp104 affect the 
propagation of $\left[\mathrm{RNQ}^{+}\right]$and $[\mathrm{PSI}+]$ differently. Another difference is that overexpression of Ssa1 (yeast Hsp70) protects [PSI+] curing by Hsp104, and the addition of both Hsp70 and Sis1 (a yeast Hsp40) promotes the severing of [ $\left.\mathrm{RNQ}^{+}\right]$amyloid fibers and further prion seeding (Newnam et al. 1999, Lopez et al. 2003, Douglas et al. 2008). In fact, all yeast prions discussed here require the presence of Sis1, but have different sensitivities to its depletion (Higurashi et al. 2008, Kirkland et al. 2011). The interactions of different yeast Hsp40s on the unique steps of prion propagation is complex and dependent on several factors. Hence, we do not provide a detailed description here (for an extensive review see Summers et al. 2009b).

Ure 2 is the protein determinant of the [URE3+] prion, and is responsible for repressing expression of nitrogen catabolic enzymes under abundant nitrogen conditions. Ure 2 contains a globular C-terminal domain, and a highly disordered $\mathrm{N}$-terminal domain, of which the latter is required for induction and propagation of the [URE3+] phenotype (Masison and Wickner 1995, Thual et al. 1999, Ngo et al. 2012). Ure2 is nonfunctional in the [URE+] form, but may form aggregates other than amyloids in vivo (Bousset et al. 2002, Ripaud et al. 2004). Expression of the yeast chaperones Ydj1 (a yeast Hsp40) and Ssa1 (yeast Hsp70) cures yeast of [Ure3+], but the cognate Sis1 Hsp40 and Ssa2/Hsp70 do not (Schwimmer and Masison 2002, Sharma et al. 2009, Xu et al. 2013). It also appears that Hsp70 nucleotide exchange factors are important in determining the [URE3+] phenotype, as both Sse1p (a nucleotide exchange factor) and Snl1p can cure [URE3+], whereas deletion of Fes1p blocks [URE3+] propagation (Kryndushkin and Wickner 2007, Kumar et al. 2014). This ability is strongly coupled to interaction with Hsp70, since a Snl1p mutant with impaired affinity for Hsp70 loses the ability to cure [URE3+] (Kumar et al. 2014).

Considering the above, the Hsp70/Hsp40 system is important in the propagation of prions (Tipton et al. 2008, Newnam et al. 2011). For instance, Hsp40/Sis1 and Hsp70/Ssa bind to prions by themselves (Jung et al. 2000, Sondheimer et al. 2001) and also assist Hsp104 interaction with prions (Tipton et al. 2008). The ratio between Hsp104 and Hsp70 may lead to bipolar responses in prion severing: when the ratio between these chaperones is balanced, severing is favored, but when an excess of Hsp104 is present, severing is inhibited (Newnam et al. 2011). Additionally, overexpression of Hsp70/Ssa1 increases the loss of the $[\mathrm{PSI}+]$ phenotype and prevents curing by excess Hsp104 (Allen et al. 2005, Mathur et al. 2009) whereas deletion of Hsp70/Ssa1 appears to have no effect on [PSI+] (Sharma and Masison 2008).

Other chaperones besides Hsp70 and Hsp40 may also be important for the action of Hsp104 on prions and aggregates, since small Hsps are found to co-elute with Hsp104 (Duennwald et al. 2012). Hsp26, a small Hsp in yeast, collaborates with Hsp104 in the solubilization of polyQ aggregates (Cashikar et al. 2005). Small Heat shock proteins are also involved in assisting Hsp104 solubilization of polyQ aggregates in rats (Perrin et al. 2007). Hsp110/Sse1, a nucleotide exchange factor and cochaperone in yeast, is required for the formation and propagation of [URE3+] (Kryndushkin and Wickner 2007) and [PSI+] (Sadlish et al. 2008). On the contrary, Btn2 and Cur1 can cure most newly formed variants of [URE3+], likely by a sequestration mechanism (Wickner et al. 2014). Regarding interaction with other co-chaperones, the C-terminus of Hsp104 (41 residues long) is similar to the C-terminal motif of Hsp90 that binds to co-chaperones containing a TPR (Tetratricopeptide Repeat). Immunoprecipitation studies have suggested that Hsp104 can also bind to these co-chaperones (Abbas-Terki et al. 2001). In fact, the Hop/Sti1 Hsp90 co-chaperone also appears to have some function in prion curing, as yeast cells deleted of Sti1 are less efficient in curing [PSI+] (Reidy and Masison 2010). In summary, the contrasting and sometimes bipolar responses of yeast prions to different chaperones and related 
proteins strongly suggests that each prion variant possesses distinct propagation requirements, with the Hsp104/Hsp70/Hsp40 systems playing major roles in this process.

Since Hsp104 is important in yeast prion biology, it has been proposed that it could also be used as a potential therapeutic tool against prionic and amyloid diseases in metazoans, which apparently lack a true disaggregase ortholog. In this respect, Hsp104 has been reported to have strong activity against amyloids (unlike ClpB), (Vashist et al. 2010), and expression of Hsp104 in mammalian cells is well tolerated. In fact, there are several examples that demonstrate beneficial effects of expressing Hsp104 in models for neurodegenerative or prionic diseases. For example, Hsp104 has been shown to convert an aggregated and protease resistant mammalian prion-like protein fragment of $\mathrm{PrP}^{\mathrm{Sc}}$ into a random coiled structure (Schirmer and Lindquist 1997, Liu et al. 2011). Additionally, Hsp104 inhibits the seeding properties of Abeta fibrils (Arimon et al. 2008), and is effective against protein aggregation (Mosser et al. 2004). Furthermore, the overexpression of Hsp104 in transgenic mice expressing the first 171 residues of mutant huntingtin, used as a model for Huntington's disease, reduced the formation of aggregates and prolonged the lifespan of the animals (Vacher et al. 2005). When Hsp104 was introduced in a rat model of Parkinson's disease, both reduction of aggregation and prevention of neurodegeneration caused by alpha-synuclein were observed (Bianco et al. 2008). Nonetheless, high Hsp104 concentrations are needed to mitigate human neurodegenerative diseases caused by protein substrates that Hsp104 never naturally encounters. Recently, exciting work has demonstrated that Hsp104 can be potentiated by some mutations to induce potent gain-offunction activities against aggregates of TDP-43, FUS, and alpha-synuclein (Jackrel et al. 2014). Therefore, heterologous expression of engineered Hsp104 could indeed be a therapeutic tool to treat amyloidogenic diseases in metazoans.

\section{SHIFTING PARADIGMS ON AGGREGATE RESOLUBILIZATION IN METAZOANS}

It is surprising that unlike yeast and plants, metazoans lack a bona fide cytosolic $\mathrm{ClpB} /$ Hsp104-like disaggregase. This is unexpected, since one would expect that such a mechanism would be present as an advantage against the deleterious actions of stress-induced and prionlike aggregates, and metazoans are subject to the same types of stress as other organisms. Several hypotheses have been proposed to explain this absence, including the role of Q-rich amyloidogenic transcription factor complexes in animal signaling mechanisms, somatic cell differentiation, and even the role of disaggregases in some biosynthetic pathways (Erives and Fassler 2015). Disaggregase activities have been reported in crude extracts of mammalian cells and C. elegans (Bieschke et al. 2009). However, these two studies were eventually partially retracted because it was determined that the activity was an artifact, resulting in surface adsorption of Abeta-fibrils to the plastic in multiwell plates and Eppendorf tubes (Murray et al. 2013). Conversely, the Hsp70/Hsp40 system alone is capable per se of dissolving small aggregate complexes, but requires the aid of Hsp 100 to recover large aggregates (Diamant et al. 2000). Likewise, it was reported that Hsp110 (an Hsp70 homolog and not to be confused with Hsp100) synergizes with Hsp70 and Hsp40 to form a machine with a weak disaggregase activity in a cell free system. However, in this case the machinery was unable to degrade amyloid conformers, was dependent on the presence of all three proteins, and was mild when compared to the rapid disaggregase activity of Hsp104 (Shorter 2008, 2011).

Hsp110 (Sse1/Sse2 in yeast) does seem to be involved in several physiological events involving protein aggregation. Hsp 110 has a function similar to that of bacterial GrpE that facilitates the exchange of ADP for ATP inducing the release of the client protein bound to DnaK (bacterial Hsp70) (Dragovic et al. 2006, Raviol et al. 2006, 
Kryndushkin and Wickner 2007) and associates with Hsp70 to form a disaggregase complex that is dependent on ATP and Hsp40 (Mattoo et al. 2013). Interestingly, knockdown of Hs110 in mice causes accumulation of hyperphosphorylated tau (a characteristic of Alzheimer disease) (Eroglu et al. 2010) and impairs the ability to refold luciferase (Yamagishi et al. 2011), whereas in C. elegans the dissolution of protein aggregates is compromised and the lifespan of the worms is shortened after heat shock (Rampelt et al. 2012). Besides being associated with aggregates, Hsp110 was enriched in a manner correlating with the relative toxicity of the aggregates when overexpressed in a human cell lineage (Olzscha et al. 2011). Other proteins also seem to collaborate with Hsp110 in a system that recovers protein aggregates in the cell, including HOP, and small Hsps (Rampelt et al. 2012, Mattoo et al. 2013, Torrente and Shorter 2014, Wolfe et al. 2013). By overexpressing amyloid-like aggregates in a human cell model, Olzscha et al. (2011) showed that Hsc70 and its co-chaperones Hsp110, Hsp40/ $\mathrm{Hdj} 1 / 2$, and Bag2 associated with the aggregates.

The fact that a disaggregase activity in metazoans evolved around the Hsp70/Hsp40 system is not a surprise as this complex has a central role in the PQC system (Douglas et al. 2009, Summers et al. 2009a, Tiroli-Cepeda and Ramos 2011) and associates with Hsp104 in yeast for full disaggregation activity (Glover and Lindquist 1998). As a matter of fact, human Hsc70 and Hsp40/Hdj1 seem to display higher intrinsic disaggregation capacity than their yeast homologs, Hsp70/Ssa1 and Hsp40s Ydj1 and Sis1 (Rampelt et al. 2012).

One emerging possibility to compensate for the loss of Hsp104 is that metazoans may have evolved multiple systems that degrade protein aggregates with weak activities but with specific cellular or tissue specific localizations (Fig. 5). This is supported by a few lines of evidence. First, the loss of bona fide Hsp104 with the emergence of multicellular organisms is abrupt. Yet, coincidentally, several AAA+ proteins appear at this time in evolution with homology to the NBD2 of Hsp104, and many contain subcellular localization targeting sequences (Breakefield et al. 2001, Torrente and Shorter 2014).

For example, the Torsin protein family is absent in unicellular organisms and plants, but animals contain up to four members (A, B, 2A, and 3A) all containing an $\mathrm{N}$-terminal endoplasmic reticulum targeting signal sequence, and a complete AAA+ module with Walker A, Walker B, sensor-1 and sensor-2 domains. Of all the torsins, torsin $\mathrm{A}$ is the most studied, since it is related to the progression of the neurological disorder known as dystonia, which has been mapped to a GAG nucleotide deletion that encodes a glutamate residue in the C-terminus of the torsin A gene product (Ozelius et al. 1997). Another intriguing feature of torsin A is its relationship with amyloidogenic neurodegenerative diseases, such as Parkinson's disease (PD). For example, Lewy bodies that are predominant in the brains of PD patients contain both torsin A and synuclein (Shashidharan et al. 2000) and torsinA overexpression has been shown to prevent Lewy body formation and suppress polyglutamine aggregation in cellular and invertebrate models (Caldwell et al. 2003, McLean et al. 2002)

Yet another interesting disaggregase candidate is called $\mathrm{Skd} 3$ (also referred to as the $\mathrm{ClpB}$ homolog), which is present in the genomes of several different organisms and shares many features with torsinA, to which it is an ortholog, including a complete $\mathrm{AAA}+$ module with canonical Walker A, Walker B, sensor-1 and sensor-2 domains, and a subcellular localization prepeptide sequence ( $\mathrm{Skd} 3$ to the mitochondria and Torsin A to the endoplasmic reticulum). In fact, the $\mathrm{ClpB}$ homolog is more closely related to Hsp104 by amino acid sequence than torsin A, sharing approximately $20 \%$ sequence identity with known Hsp104/ClpB members, which increases to $40 \%$ identity and $65 \%$ similarity within the single nucleotide binding domain (Jossé et al. 2010). Interestingly, the $\mathrm{ClpB}$ ortholog contains up to four ankyrin repeats at the N-terminus, which is a unique feature not shared with either Hsp104 




Figure 5 - Proposed Mechanism of Gene Loss and Gain in the Stem-metazoan Lineage as Applied to Disaggregase Activities. While Bona fide Hsp104 orthologs are highly conserved in bacteria, plants, yeast, and relatives of pre-metazoan containing receptor tyrosine kinases (RTKs), they are absent in modern metazoans. This may be due to a number of factors including loss of biosynthetic pathways requiring Hsp100s (Hsp104 and Hsp78), complex cell signaling involving amyloidogenic transcription factor (TF) complexes, and the specialization of hypothetical weak disaggregases with high specificities and localizations, such as the torsins in the endoplasmic reticulum (ER), and ClpBHH in the mitochondria. *RTKs = Receptor Tyrosine Kinases.

nor any member within the torsin family. In summary, several metazoan proteins may function cooperatively in different cellular compartments to eliminate protein aggregates in the cell, and we are just now beginning to understand which protein players are responsible for this activity.

\section{CONCLUSIONS}

The formation of amyloid-like aggregates is associated with hundreds of diseases, many of which lack a therapeutic treatment or cure. The general accumulation of amyloid-like aggregates and prions inside the cell seems to have a proteotoxic effect, at least in the long term, because these species can template soluble proteins when in contact with them. Cells have a Protein Quality Control (PQC) system that deals with protein folding and misfolding. Among the proteins involved in the PQC, the ClpB/Hsp104 family has captured broad attention because it has the formidable ability to ressolubilize and reactivate aggregated proteins. Although lacking a disaggregase specialist in its genome, metazoans have evolved one or more disaggregase-like systems around Hsp70 and its co-chaperones, that appears to be quite efficient in suppressing proteotoxicity in several cell lines. However, due to the sensitivity of metazoan cells to aging, this system may not be sufficient to compensate for the lack of an Hsp100-like chaperone, especially considering that the disaggregase machines in metazoans act much slower than Hsp104, and may be localized to specific cellular compartments (Shorter 2011).

\section{ACKNOWLEDGMENTS}

We thank Fundação de Amparo à Pesquisa do Estado de São Paulo (FAPESP), Conselho Nacional de Desenvolvimento Científico e Tecnológico (CNPq), and Coordenação de Aperfeiçoamento de Pessoal de Nível Superior (CAPES) for financial support and fellowships.

\section{RESUMO}

O processo de enovelamento é um evento importante para o tempo de vida de uma proteína, uma vez que é essencial para a função adequada da proteína e, por conseguinte, para a fisiologia celular. Enovelamento inadequado, ou mau enovelamento, pode não só conduzir à perda de função, mas também para a formação de agregados de proteína, uma associação insolúvel de polipeptídos que prejudicam a fisiologia celular, quer por si próprios ou no processo de formação. Vários processos biológicos 
têm evoluído para prevenir e eliminar a existência de agregados não funcionais e amiloidogênicos, uma vez que estão associados com várias patologias humanas. Chaperonas moleculares e proteínas de choque térmico são especializadas no controle de qualidade de proteínas na célula, especificamente, auxiliando o enovelamento correto, dissolução e remoção de agregados de proteína já formados. Esta última é uma função das 'disagregases', representadas principalmente pela subfamília $\mathrm{ClpB} /$ Hsp104 de chaperonas moleculares, que são comuns em todos os organismos, mas, surpreendentemente, não possuem ortólogos no citosol de células de metazoários. Esta revisão tem como objetivo descrever as características das disagregases e discutir a função da Hsp104 de levedura, uma disagregase que também está envolvida na propagação e herança de príons.

Palavras-chave: amilóide, desagregase, proteínas do choque térmico, chaperonas moleculares, príons, enovelamento de proteínas.

\section{REFERENCES}

ABBAS-TERKI T, DONZ O, BRIAND PA AND PICARD D. 2001. Hsp104 interacts with Hsp90 cochaperones in respiring yeast. Mol Cell Biol 21: 7569-7575.

ALlen KD, Wegrzyn RD, Chernova TA, MÜller S, NEWNAM GP, WINSLETT PA, WiTTICHK B, WILKINSON KD AND CHERNOFF YO. 2005. Hsp70 chaperones as modulators of prion life cycle: novel effects of Ssa and Ssb on the Saccharomyces cerevisiae prion [PSI+]. Genetics 169: 1227-1242.

ARIMON M, GRIMMINGER V, SANZ F AND LASHUEL HA. 2008. Hsp104 targets multiple intermediates on the amyloid pathway and suppresses the seeding capacity of Abeta fibrils and protofibrils. J Mol Biol 384: 1157-1173.

ARRASATE M, Mitra S, SCHWEITZER ES, SEgal MR AND FINKBEINER S. 2004. Inclusion body formation reduces levels of mutant huntingtin and the risk of neuronal death. Nature 431: 805-810.

BALDWIN RL AND ROSE GD. 2013. Molten globules, entropydriven conformational change and protein folding. Curr Opin Struct Biol 23: 4-10.

BARDILl JP, DULLE JE, Fisher JR AND TRUE HL. 2009. Requirements of Hsp104p activity and Sis $1 \mathrm{p}$ binding for propagation of the $[\mathrm{RNQ}(+)]$ prion. Prion 3: 151-160.

BARENDS TRM, WERBECK ND AND REINSTEIN J. 2010. Disaggregases in 4 dimensions. Curr Opin Struct Biol 20: 46-53.

BARNETT ME, NAGY M, KEDZIERSKA S AND ZOLKIEWSKI M. 2005. The amino-terminal domain of ClpB supports binding to strongly aggregated proteins. J Biol Chem 280 : 34940-34945.

BeINKER P, SCHLEE S, GROEMPING Y, SEIDEL R AND REINSTEIN J. 2002. The $\mathrm{N}$ terminus of ClpB from Thermus thermophilus is not essential for the chaperone activity. $\mathrm{J}$ Biol Chem 277: 47160-47166.

Bianco CL, Shorter J, RÉGulier E, LASHUEl H, IWATSUBO T, LINDQUIST S AND AEBISCHER P. 2008. Hsp104 antagonizes alpha-synuclein aggregation and reduces dopaminergic degeneration in a rat model of Parkinson disease. J Clin Invest 118: 3087-3097.

BIESCHKe J, COHEN E, MuRRAY A, Dillin A AND Kelly JW. 2009. A kinetic assessment of the C. elegans amyloid disaggregation activity enables uncoupling of disassembly and proteolysis. Protein Sci 18: 2231-2241.

BORGES JC, SERAPHIM TV, MOKRY DZ, ALMEIDA FCL, CYR DM AND RAMOS CHI. 2012. Identification of regions involved in substrate binding and dimer stabilization within the central domains of yeast Hsp40 Sis1. PloS One 7: e50927.

BÖSL B, GRIMMinger V AND WALTER S. 2006. The molecular chaperone Hsp104 - a molecular machine for protein disaggregation. J Struct Biol 156: 139-148.

Bousset L, THOMSON NH, RADFORD SE AND MELKI R. 2002. The yeast prion Ure $2 p$ retains its native $\alpha$-helical conformation upon assembly into protein fibrils in vitro. EMBO J 21: 2903-2911.

BREAKEFIELD XO, KAMM C AND HANSON PI. 2001. TorsinA: movement at many levels. Neuron 31: 9-12.

BuKAU B AND HoRwich AL. 1998. The Hsp70 and Hsp60 chaperone machines. Cell 92: 351-366.

CAgliari TC, Silva VC, Borges JC, PRANDO A, TASIC L AND RAMOS CH. 2011. Sugarcane Hsp101 is a hexameric chaperone that binds nucleotides. Int J Biol Macromol 49: 1022-1030.

Caldwell GA, CaO S, SeXton EG, Gelwix CC, BeVEl JP AND CALDWELL KA. 2003. Suppression of polyglutamineinduced protein aggregation in Caenorhabditis elegans by torsin proteins. Hum Mol Genet 12: 307-319.

CASHIKAR AG, DUENNWALD M AND LINDQUIST SL. 2005. A chaperone pathway in protein disaggregation. Hsp26 alters the nature of protein aggregates to facilitate reactivation by Hsp104. J Biol Chem 280: 23869-23875.

CHENG IH ET AL. 2007. Accelerating amyloid-beta fibrillization reduces oligomer levels and functional deficits in Alzheimer disease mouse models. J Biol Chem 282: 23818-23828.

CHERNOFF YO, LINDQUist SL, ONO B, INGE-VECHTOMOV SG AND LIEBMAN SW. 1995. Role of the chaperone protein Hsp104 in propagation of the yeast prion-like factor [PSI+]. Science 268: 880-884. 
CHIEN P, WEISSMAN JS AND DEPACE AH. 2004. Emerging principles of conformation-based prion inheritance. Annu Rev Biochem 73: 617-656.

Chiti F AND Dobson CM. 2006. Protein misfolding, functional amyloid and human disease. Annu Rev Biochem 75: 333-366.

COllins SR, Douglas A, VAle RD AND WeISSMAN JS. 2004. Mechanism of prion propagation: amyloid growth occurs by monomer addition. PLoS Biol 2: e321.

DA SILVA VC AND RAMOS CHI. 2012. The network interaction of human $90 \mathrm{kDa}$ heat shock protein Hsp90: a target for cancer therapeutics. J Proteomics 75: 2790-2802.

DERKATCH IL, BRADLEY ME, ZHOU P, CHERNOFF YO AND LIEBMAN SW. 1997. Genetic and environmental factors affecting the de novo appearance of the [PSI+] prion in Saccharomyces cerevisiae. Genetics 147: 507-519.

DESANTis ME, LEUnGH EH, SWENNy EA, JACKREL ME, CUSHMAN-Nick M, NeUHAUS-FOllini A, VASHist S, SOCHOR MA, KNIGHT MN AND SHORTER J. 2012. Operational plasticity enables Hsp104 do disaggregate diverse amyloid and nonamyloid clients. Cell 151: 778793.

DESANTIS ME AND SHORTER J. 2012. The elusive middle domain of Hsp104 and ClpB: location and function. Biochim Biophys Acta 1823: 29-39.

DiAMANT S, BEN-ZVI AP, BUKAU B AND GOLOUBINOFF P. 2000. Size-dependent disaggregation of stable protein aggregates by the DnaK chaperone machinery. J Bio Chem 275: 21107-21113.

DILl KA AND MACCALLUM JL. 2012. The protein-folding problem, 50 years on. Science 338: 1042-1046.

DOBSON CM. 2004. Experimental investigation of protein folding and misfolding. Methods 34: 4-14.

DougAn DA, MogK A AND BUKAU B. 2002. Protein folding and degradation in bacteria: to degrade or not to degrade? That is the question. Cell Mol Life Sci 59: 1607-1616.

DOUGLAS PM, SUMMERS DW AND CYR DM. 2009. Molecular chaperones antagonize proteotoxicity by differentially modulating protein aggregation pathways. Prion 3: 51-58.

Douglas PM, TREusch S, REN H, HALFMANN R, DUENNWALD ML, LINDQUIST S AND CYR DM. 2008. Chaperone-dependent amyloid assembly protects cells from prion toxicity. Proc Natl Acad Sci USA 105: 72067211.

Doyle SM, Genest O AND WiCKNer S. 2013. Protein rescue from aggregates by powerful molecular chaperone machines. Nat Rev Mol Cell Bio 14: 617-629.

DOYLE SM, SHORTER J, ZOLKIEWSKI M, HOSKINS JR, LINDQUIST S AND WICKNER S. 2007. Asymmetric deceleration of ClpB or Hsp104 ATPase activity unleashes protein-remodeling activity. Nat Struct Mol Biol 14: 114122.
DRAGOVIC Z, BROADLEY SA, SHOMURA Y, BRACHER A AND HARTL FU. 2006. Molecular chaperones of the Hsp110 family act as nucleotide exchange factors of Hsp70s. EMBO J 25: 2519-2528.

DUENNWALD ML, ECHEVERRIA A AND SHORTER J. 2012. Small heat shock proteins potentiate amyloid dissolution by protein disaggregases from yeast and humans. PLoS Biol 10: e1001346.

DULle JE, STEIN KC AND TRUE HL. 2014. Regulation of the Hsp104 middle domain activity is critical for yeast prion propagation. PLoS One 9: e87521.

EISENBERG D AND JUCKER M. 2012. The amyloid state of proteins in human diseases. Cell 148: 1188-1203.

ERIVES A AND FASSLER J. 2015. Metabolic and Chaperone Gene Loss Marks the Origin of Animals: Evidence for Hsp104 and Hsp78 Chaperones Sharing Mitochondrial Enzymes as Clients. PLos One 10(2): e0117192.

ERJAVEC N, LARSSON L, GRANTHAM J AND NYSTROM T. 2007. Accelerated aging and failure to segregate damaged proteins in Sir2 mutants can be suppressed by overproducing the protein aggregation remodeling factor Hsp104p. Genes Dev 21: 2410-2421.

EROGLU B, MOSKOPHIDIS D AND MIVECHI NF. 2010. Loss of Hsp110 leads to age-dependent tau hyperphosphorylation and early accumulation of insoluble amyloid beta. Mol Cell Biol 30: 4626-4643.

FAN C, LEE S AND CYR DM. 2003. Mechanisms for regulation of Hsp70 by Hsp40. Cell Stress Chaperon 8: 309-316.

FERREIRA PC, NESS F, EDWARDS SR, COX BS AND TUITE MF. 2001. The elimination of the yeast [PSI+] prion by guanidine hydrochloride is the result of Hsp104 inactivation. Mol Microbiol 40: 1357-1369.

FINKA A AND GolOUBINOFF P. 2013. Proteomic data from human cell cultures refine mechanisms of chaperonemediated protein homeostasis. Cell Stress Chaperon 18: 591-605.

Fowler DM, KOULOV AV, AlORY-Jost C, MARKS MS, BALCH WE AND KELLY JW. 2006. Functional amyloid formation within mammalian tissue. PLoS Biol 4: e6.

GIERASCH LM AND KING J. 1990. Protein folding: deciphering the second half of the genetic code. Science. University of York, Department of Chemistry, York Y01 5DD, UK.

GLOVER JR AND LINDQUIST S. 1998. Hsp104, Hsp70, and Hsp40: a novel chaperone system that rescues previously aggregated proteins. Cell 94: 73-82.

GoloubinOfF P, MOGK A, ZVI APB, TOMOYASU T AND BUKAU B. 1999. Sequential mechanism of solubilization and refolding of stable protein aggregates by a bichaperone network. Proc Natl Acad Sci USA 96: 13732-13737.

GRIMMINGER V, RICHTER K, IMHOF A, BUCHNER J AND WALTER S. 2004. The prion curing agent guanidinium chloride specifically inhibits ATP hydrolysis by Hsp104. J Biol Chem 279: 7378-7383. 
HARTL FU, BRACHER A AND HAYER-HARTL M. 2011. Molecular chaperones in protein folding and proteostasis. Nature 475: 324-332.

HATTENDORF DA AND LINDQUIST S. 2002. Cooperative kinetics of both Hsp104 ATPase domains and interdomain communication revealed by AAA sensor-1 mutants. EMBO J 21: 12-21a.

Higurashi T, Hines JK, SAHI C, ARON R AND CRAig EA. 2008. Specificity of the J-protein Sis 1 in the propagation of 3 yeast prions. Proc Natl Acad Sci USA 105: 1659616601 .

Hodson S, MARShall JJ AND BURSTON SG. 2012. Mapping the road to recovery: the $\mathrm{ClpB} / \mathrm{Hsp} 104$ molecular chaperone. J Struct Biol 179: 161-171.

HUNG G AND MASISON DC. 2006. N-terminal domain of yeast Hsp104 chaperone is dispensable for thermotolerance and prion propagation but necessary for curing prions by Hsp104 overexpression. Genetics 173: 611-620.

INGE-VECHTOMOV SG, ZHOURAVLEVA GA AND CHERNOFF YO. 2007. Biological roles of prion domains. Prion 1: 228235.

JACKREL ME, DESANTIS ME, MARTINEZ BA, CASTELLANO LM, STEWART RM, CALDWELL KA, CALDWELL GA AND SHORTER J. 2014. Potentiated Hsp104 variants antagonize diverse proteotoxic misfolding events. Cell 156: 170-182.

Jossé L, SMALES CM AND TUITE MF. 2010. Transient expression of human TorsinA enhances secretion of two functionally distinct proteins in cultured Chinese hamster ovary (CHO) cells. Biotechnol Bioeng 105: 556-566.

JUNG G, JONES G, WEGRZYN RD AND MASISON DC. 2000. A role for cytosolic hsp70 in yeast [PSI $(+)]$ prion propagation and $[\mathrm{PSI}(+)]$ as a cellular stress. Genetics 156: 559-570.

KIM KI, CHEONG GW, PARK SC, HA SJ, WOO KM, CHOI SJ AND CHUNG CH. 2000. Heptameric ring structure of the heat-shock protein $\mathrm{ClpB}$, a protein-activated ATPase in Escherichia coli. J Mol Biol 303: 655-666.

KIM YE, HIPP MS, BRACHER A, HAYER-HARTL M AND HARTL FU. 2013. Molecular chaperone functions in protein folding and proteostasis. Annu Rev Biochem 82: 323-355.

KIRKLAND PA, REIDY M AND MASISON DC. 2011. Functions of yeast Hsp40 chaperone Sis1p dispensable for prion propagation but important for prion curing and protection from prion toxicity. Genetics 188: 565-577.

KNOWLES TPJ, VendRUSCOLO M AND DOBSON CM. 2014. The amyloid state and its association with protein misfolding diseases. Nat Rev Mol Cell Biol 15: 384-396.

KRYNDUSHKIN D AND WICKNER RB. 2007. Nucleotide exchange factors for Hsp70s are required for [URE3] prion propagation in Saccharomyces cerevisiae. Mol Biol Cell 18: 2149-2154.

Kumar N, Gaur D, Masison CD AND Sharma D. 2014. The BAG homology domain of Snl1 cures yeast prion
[URE3] through regulation of Hsp70 chaperones. G3 4: 461-470.

Kummer E, OGUChI Y, SEYFFER F, BUKAU B AND MOGK A. 2013. Mechanism of Hsp104/ClpB inhibition by prion curing Guanidinium hydrochloride. FEBS Lett 587: 810817.

KURAHASHI H, OISHI K AND NAKAMURA Y. 2011. A bipolar personality of yeast prion proteins. Prion 5: 305-310.

LeE S, Sowa ME, Watanabe YH, Sigler PB, ChiU W, YOSHIDA M AND TSAI FT. 2003. The structure of ClpB: a molecular chaperone that rescues proteins from an aggregated state. Cell 115: 229-240.

LEE YR, NAGAO RT AND KEY JL. 1994. A soybean 101-kDa heat shock protein complements a yeast HSP104 deletion mutant in acquiring thermotolerance. Plant Cell 6: 18891897.

LINDQUIST S. 1997. Mad cows meet psi-chotic yeast: the expansion of the prion hypothesis. Cell 89: 495-498.

LINDQUIST S AND KIM G. 1996. Heat-shock protein 104 expression is sufficient for thermotolerance in yeast. Proc Natl Acad Sci USA 93: 5301-5306.

LIPIŃSKA N ET AL. 2013. Disruption of ionic interactions between the nucleotide binding domain 1 (NBD1) and middle (M) domain in Hsp100 disaggregase unleashes toxic hyperactivity and partial independence from Hsp70. J Biol Chem 288: 2857-2869.

LIU YH ET AL. 2011. Heat shock protein 104 inhibited the fibrillization of prion peptide 106-126 and disassembled prion peptide 106-126 fibrils in vitro. Int J Biochem Cell Biol 43: 768-774.

LOPEZ N, ARON R AND CRAIG EA. 2003. Specificity of class II Hsp40 Sis1 in maintenance of yeast prion [RNQ(+)]. Mol Biol Cell 14: 1172-1181.

MACKAY RG, HELSEN CW, TKACH JM AND GLOVER JR. 2008. The C-terminal extension of Saccharomyces cerevisiae Hsp104 plays a role in oligomer assembly. Biochemistry 47: 1918-1927.

MASISON DC AND WICKNER RB. 1995. Prion-inducing domain of yeast Ure $2 p$ and protease resistance of Ure $2 p$ in prion-containing cells. Science 270: 93-95.

MATHUR V, Hong JY AND LIEBMAN SW. 2009. Ssa 1 overexpression and $[\mathrm{PIN}(+)]$ variants cure $[\mathrm{PSI}(+)]$ by dilution of aggregates. J Mol Biol 390: 155-167.

MatToo RU, ShARMA SK, PRIYA S, FINKA A AND GOLOUBINOFF P. 2013. Hsp110 is a bona fide chaperone using ATP to unfold stable misfolded polypeptides and reciprocally collaborate with Hsp70 to solubilize protein aggregates. J Biol Chem 288: 21399-21411.

MAYER MP. 2010. Gymnastics of molecular chaperones. Mol Cell 39: 321-331.

MCLEAN PJ, KAWAMATA H, SHARIFF S, HEWETT J, SHARMA N, UEDA K, BREAKEFIELD XO AND HYMAN BT. 2002. TorsinA and heat shock proteins act as molecular 
chaperones: suppression of alpha-synuclein aggregation. J Neurochem 83: 846-854.

MERIIN AB, ZHANG X, HE X, NeWNAM GP, CHERnOFF YO AND SHERMAN MY. 2002. Huntington toxicity in yeast model depends on polyglutamine aggregation mediated by a prion-like protein Rnq1. J Cell Biol 157: 997-1004.

Miot M, REIDY M, DOYLE SM, HOSKINS JR, JOHNSTON DM, GENEST O, VITERY M, MASISON DC AND WICKNER S. 2011. Species-specific collaboration of heat shock proteins (Hsp) 70 and 100 in thermotolerance and protein disaggregation. Proc Natl Acad Sci USA 108: 6915-6920.

Mogk A, Schlieker C, Strub C, Rist W, Weibezahn J AND BUKAU B. 2003. Roles of individual domains and conserved motifs of the AAA+ chaperone ClpB in oligomerization, ATP hydrolysis, and chaperone activity. J Biol Chem 278: 17615-17624.

Mogk A, TOMOYASU T, GoloubinofF P, RÜdiger S, RÖDER D, LANGEN H AND BUKAU B. 1999. Identification of thermolabile Escherichia coli proteins: prevention and reversion of aggregation by DnaK and ClpB. EMBO J 18: 6934-6949.

MORIMOTO RI. 2011. The heat shock response: systems biology of proteotoxic stress in aging and disease. Cold Spring Harb Symp Quant Biol 76: 91-99.

MORIYAMA H, EDSKES HK AND WICKNER RB. 2000. [URE3] prion propagation in Saccharomyces cerevisiae: Requirement for chaperone Hsp104 and curing by overexpressed chaperone Ydj1p. Mol Cell Biol 20: 89168922.

Mosser DD, Ho S AND GLOVER JR. 2004. Saccharomyces cerevisiae Hsp104 enhances the chaperone capacity of human cells and inhibits heat stress-induced proapoptotic signaling. Biochemistry 43: 8107-8115.

MurRAY AN, PALHANO FL, BIESCHKE J AND KELLY JW. 2013. Surface adsorption considerations when working with amyloid fibrils in multi-well plates and eppendorf tubes. Protein Sci 22: 1531-1541.

NEWNAM GP, BIRCHMORE JL AND CHERNOFF YO. 2011. Destabilization and recovery of a yeast prion after mild heat shock. J Mol Biol 408: 432-448.

NEWNAM GP, WEGRZYN RD, LINDQUIST SL AND CHERNOFF YO. 1999. Antagonistic interactions between yeast chaperones Hsp104 and Hsp70 in prion curing. Mol Cell Biol 19: 1325-1333.

Ngo S, Chiang V, Ho E, LE L And Guo Z. 2012. Prion domain of yeast Ure2 protein adopts a completely disordered structure: a solid-support EPR study. PLoS One 7: e7248.

NOWICKI L, LEZNICKI P, MORAWIEC E, LITWINCZUK N AND LIBEREK K. 2011. Role of a conserved aspartic acid in nucleotide binding domain 1 (NBD1) of Hsp100 chaperones in their activities. Cell Stress Chaperon 17: 361-373.
OGUCHI Y, KUMMER E, SEYFFER F, BERYNSKYY M, ANSTETT B, ZAHN R, WADE RC, MOGK A AND BUKAU B. 2012. A tightly regulated molecular toggle controls AAA+ disaggregase. Nat Struct Mol Biol 19: 1338-1346.

OLZSCHA H, SCHERMANN MS, WOERNER AC, PINKERT S, Hecht HM, TARTaglia GG, Vendruscolo M, HAYER-HARTL M, HARTL FU AND VABULAS RM. 2011. Amyloid-like aggregates sequester numerous metastable proteins with essential cellular functions. Cell 144: 67-78.

OSHEROVICH LZ AND WEISSMAN JS. 2001. Multiple Gln/ Asn-rich prion domains confer susceptibility to induction of the yeast [PSI $(+)]$ prion. Cell 106: 183-194.

OZELIUS LJ ET AL. 1997. The early-onset torsion dystonia gene (DYT1) encodes an ATP-binding protein. Nat Genet 17: 40-48.

PAK M, HOSKIN JR, SINGH SK, MAURIZI MR AND WICKNER S. 1999. Concurrent Chaperone and Protease Activities of ClpAP and the Requirement for the N-terminal ClpA ATP Binding Site for Chaperone Activity. J Biol Chem 274: 19316-19322.

PARSEll DA, KowAl AS, SINGER MA AND LiNDQUIST S. 1994. Protein disaggregation mediated by heat-shock protein Hsp104. Nature 372: 475-478.

PARSELL DA, SANCHEZ Y, STITZEL JD AND LINDQUIST S. 1991. Hsp104 is a highly conserved protein with two essential nucleotide-binding sites. Nature 353: 270-273.

PATEL S AND LATTERICH M. 1998. The AAA team: related ATPases with diverse functions. Trends Cell Biol 8: 65-71.

PAUSHKIN SV, KUSHNIROV VV, SMIRNOV VN AND TERAVANESYAN MD. 1996. Propagation of the yeast prionlike [psi+] determinant is mediated by oligomerization of the SUP35-encoded polypeptide chain release factor. EMBO J 15: 3127-3134.

PERrin V, REgUlier E, ABBAS-TERKI T, HASSIG R, Brouillet E, AEBischer P, LUTHI-CARTER R AND DÉGLON N. 2007. Neuroprotection by Hsp104 and Hsp27 in lentiviral-based rat models of Huntington's disease. Mol Ther 15: 903-911.

PICCARDO P, MANSON JC, KING D, GHETTI B AND BARRON RM. 2007. Accumulation of prion protein in the brain that is not associated with transmissible disease. Proc Natl Acad Sci 104: 4712-4717.

PRIYA S, SHARMA SK AND GOLOUBINOFF P. 2013. Molecular chaperones as enzymes that catalytically unfold misfolded polypeptides. FEBS Lett 587: 1981-1987.

QUEITSCH C, HONG SW, VIERLING E AND LINDQUIST S. 2000. Heat shock protein 101 plays a crucial role in thermotolerance in Arabidopsis. Plant Cell 12: 479-492.

RAMOS CHI AND FERREIRA ST. 2005. Protein folding, misfolding and aggregation: evolving concepts and conformational diseases. Protein Pept Lett 12: 213-222.

RAmpelt H, Kirstein-Miles J, Nillegoda NB, CHI K, Scholz SR, Morimoto RI AND BUKAU B. 2012. 
Metazoan Hsp70 machines use Hsp110 to power protein disaggregation. EMBO J 31: 4221-4235.

RAVIOL H, SADLISH H, RODRIGUEZ F, MAYER MP AND BUKAU B. 2006. Chaperone network in the yeast cytosol: Hsp110 is revealed as an Hsp70 nucleotide exchange factor. EMBO J 25: 2510-2518.

REIDY M AND MASISON DC. 2010. Sti1 regulation of Hsp70 and Hsp90 is critical for curing of Saccharomyces cerevisiae [PSI+] prions by Hsp104. Mol Cell Biol 30: 3542-3552.

RIPAUD L, MAILLET L, IMMEL-TORTEROTOT F, DURAND F AND CULLIN C. 2004. The [URE3] yeast prion results from protein aggregates that differ from amyloid filaments formed in vitro. J Biol Chem 279: 50962-50968.

ROMANOVA NV AND CHERNOFF YO. 2009. Hsp104 and prion propagation. Prot Pept Lett 16: 598-605.

SADLISH H, RAMPELT H, SHORTER J, WEGRZYN RD, REASSON C, LINDQUIST S AND BUKAU B. 2008. Hsp110 chaperones regulate prion formation and propagation in $S$. cerevisiae by two discrete activities. PLoS One 3: 1763.

SANCHEZ Y AND LINDQUIST SL. 1990. Hsp104 required for induced thermotolerance. Science 248: 1112-1115.

SANCHEZ Y, TAULIEN J, BORKOVICH KA AND LINDQUIST S. 1992. Hsp104 is required for tolerance to many forms of stress. EMBO J 11: 2357-2364.

SATPUTE-KRISHNAN P, LANGSETH SX AND SERIO TR. 2007. Hsp104-dependent remodeling of prion complexes mediates protein-only inheritance. PLoS Biol 5: e24.

SAUER RT ET AL. 2004. Sculpting the proteome with AAA(+) proteases and disassembly machines. Cell 2004 119: 9-18.

SCHIRMER EC, GLOVER JR, SINGER MA AND LINDQUIST S. 1996. HSP100/Clp proteins: a common mechanism explains diverse functions. Trends Biochem Sci 8: 289-296.

SCHIRMER EC, HOMANN OR, KOWAL AS AND LINDQUIST S. 2004. Dominant Gain-of-function mutations in Hsp104p reveal crucial roles for the middle region. Mol Biol Cell 15: 2061-2072.

SCHIRMER EC AND LINDQUIST S. 1997. Interactions of the chaperone Hsp104 with yeast Sup35 and mammalian PrP. Proc Natl Acad Sci USA 25: 13932-13937.

SCHIRMER EC, QUEITSCH C, KOWAL AS, PARSELL AD AND LINDQUIST S. 1998. The ATPase activity of Hsp104, effects of environmental conditions and mutations. J Biol Chem 273: 15546-15552.

SCHLEE S, BEINKER P, AKHRYMUK A AND REINSTEIN J. 2004. A chaperone network for the resolubilization of protein aggregates: direct interaction of $\mathrm{ClpB}$ and DnaK. J Mol Biol 336: 275-285.

SCHLIEKER C, TEWs I, BuKAu B AND MoGK A. 2004. Solubilization of aggregated proteins by $\mathrm{ClpB} / \mathrm{DnaK}$ relies on the continuous extraction of unfolded polypeptides. FEBS Lett 578: 351-356.
SCHWIMMER C AND MASISON DC. 2002. Antagonistic interactions between yeast [PSI+] and [URE3] prions and curing of [URE3] by Hsp70 protein chaperone Ssa1p but not by Ssa2p. Mol Cell Biol 22: 3590-3598.

SEOL JH, BAEK SH, KANG M, HA DB AND CHUNG CH. 1995. Distinctive roles of the two ATP-binding sites in ClpA, the ATPase component of protease Ti in Escherichia coli. J Biol Chem 270: 8087-8092.

SHARMA D AND MASISON DC. 2008. Functionally redundant isoforms of a yeast Hsp70 chaperone subfamily have different antiprion effects. Genetics 179: 1301-1311.

SHARMA D, STANLEY R AND MASISON DC. 2009. Curing of Yeast [URE3] Prion by the Hsp40 Cochaperone Ydj1p Is Mediated by Hsp70. Genetics 181: 129-137.

SHASHIDHARAN P, GOOD PF, HSU A, PERL DP, BRIN MF AND OLANOW CW. 2000. TorsinA accumulation in Lewy bodies in sporadic Parkinson's disease. Brain Res 877: 379-381.

SHORTER J. 2008. Hsp104: a weapon to combat diverse neurodegenerative disorders. NeuroSignals 16: 63-74.

SHORTER J. 2011. The mammalian disaggregase machinery: Hsp110 synergizes with Hsp70 and Hsp40 to catalyze protein disaggregation and reactivation in a cell-free system. PLoS One 6: e26319.

SHORTER J AND LINDQUIST S. 2004 Hsp104 catalyzes formation and elimination of self-replicating Sup35 prion conformers. Science 304: 1793-1797.

SHORTER J AND LINDQUIST S. 2005. Prions as adaptive conduits of memory and inheritance. Nat Rev Genet 6: 435-450.

SIELAFF B AND TSAI FT. 2010. The M-domain controls Hsp104 protein remodeling activity in an Hsp70/Hsp40dependent manner. J Mol Biol 402: 30-37.

SINGH SK AND MAURIZI MR. 1994. Mutational analysis demonstrates different functional roles for the two ATPbinding sites in ClpAP protease from Escherichia coli. J Biol Chem 269: 29537-29545.

SNIDER J AND HOURY WA. 2008. AAA+ proteins: diversity in function, similarity in structure. Biochem Soc Trans 36: $72-77$.

SONDHEIMER N AND LINDQUist S. 2000. Rnq1: an epigenetic modifier of protein function in yeast. Mol Cell 5: 163-172.

SONDHEIMER N, LOPEZ N, CRAIG EA AND LINDQUIST S. 2001. The role of Sis 1 in the maintenance of the [RNQ+] prion. EMBO J 20: 2435-2442.

SuMMers DW, DOUGLAS PM AND CYR DM. 2009b. Prion propagation by Hsp40 molecular chaperones. Prion 3: 59-64.

SumMERS DW, DOUGLAS PM, RAMOS CHI AND CYR DM. 2009a. Polypeptide transfer from Hsp40 to Hsp70 molecular chaperones. Trends in Biochem Sc 34: 230233. 
SUNDE M AND BLAKE C. 1997. The structure of amyloid fibrils by electron microscopy and X-ray diffraction. Adv Protein Chem 50: 123-159.

SUZUKI G AND TANAKA M. 2012. Active conversion to the prion state as a molecular switch for cellular adaptation to environmental stress. Bioessays 35: 12-16.

TANAKA M, CHIEN P, NABER N, COOKE R AND WEISSMAN JS. 2004. Conformational variations in an infectious protein determine prion strain differences. Nature 428: 323-328.

TANeJA V, MAdDELEIN M, TALAREK N, SAUPE SJ AND LIEBMAN SW. 2007. A non-Q/N-rich prion domain of a foreign prion, [Het-s], can propagate as a prion in yeast. Mol Cell 27: 67-77.

TESSARZP, MOGKAAND BUKAU B. 2008. Substrate threading through the central pore of the Hsp104 chaperone as a common mechanism for protein disaggregation and prion propagation. Mol Microbiol 68: 87-97.

Thual C, Komar AA, Bousset L, FERnAndezBellot E, Cullin C AND MelKi R. 1999. Structural characterization of Saccharomyces cerevisiae prion-like protein Ure2. J Biol Chem 274: 13666-13614.

TIPTON KA, VERGES KJ AND WEISSMAN JS. 2008. In vivo monitoring of the prion replication cycle reveals a critical role for Sis1 in delivering substrates to Hsp104. Mol Cell 32: 584-591.

TIROLI-CEPEDA A AND RAMOS CHI. 2011. An overview of the role of molecular chaperones in protein homeostasis. Protein Pept Lett 18: 101-109.

TORRENTE MP AND SHORTER J. 2014. The metazoan protein disaggregase and amyloid depolymerase system: Hsp110, Hsp70, Hsp40, and small heat shock proteins. Prion 7: 457-463.

TUITE MF, MUNDY CR AND COX BS. 1981. Agents that cause a high frequency of genetic change from [psi+] to [psi-] in Saccharomyces cerevisiae. Genetics 98: 691711.

TUITE MF AND SERIO TR. 2010. The prion hypothesis: from biological anomaly to basic regulatory mechanism. Nat Rev Mol Cell Biol 11: 823-833.

UPTAIN SM AND LINDQUIST S. 2002. Prions as proteinbased genetic elements. Annu Rev Microbiol 56: 703741.

VACHER C, GARCIA-OROZ L AND RUBINSZTEIN DC. 2005. Overexpression of yeast hsp104 reduces polyglutamine aggregation and prolongs survival of a transgenic mouse model of Huntington's disease. Hum Mol Genet 14: 3425-3433.

VASHIST S, CUSHMAN M AND SHORTER J. 2010. Applying Hsp104 to protein-misfolding disorders. Biochem Cell Biol 88: 1-13.

VITRENKO YA, GRACHEVA EO, RICHMOND JE AND LIEBMAN SW. 2007. Visualization of aggregation of the
Rnq1 prion domain and cross-seeding interactions with Sup35NM. J Biol Chem 282: 1779-1787.

WEGRZYN RD, BAPAT K, NEWNAM GP, ZINK AD AND CHERNOFF YO. 2001. Mechanism of prion loss after Hsp104 inactivation in yeast. Mol Cell Biol 21: 46564669.

WEIBEZAHN J ET AL. 2004. Thermotolerance requires refolding of aggregated proteins by substrate translocation through the central pore of ClpB. Cell 119: 653-665.

WENDLER P AND SAIBIL HR. 2010. Cryo-electron microscopy structures of Hsp100 proteins-crowbars in or out. Biochem Cell Biol 88: 89-96.

WICKNER RB. 1994. [URE3] as an altered URE2 protein: evidence for a prion analog in Saccharomyces cerevisiae. Science 264: 566-569.

WICKNER RB, BEZSONOV E AND BATEMAN DA. 2014. Normal levels of the antiprion proteins Btn2 and Cur1 cure most newly formed [URE3] prion variants. Proc Natl Acad Sci USA 111: E2711-2720.

WICKNER RB, EDSKES HK, BATEMAN D, KELLY AC AND GORKOVSKIY A. 2011. The yeast prions [PSI+] and [URE3] are molecular degenerative diseases. Prion 5: 258-262.

WinkLER J, TYEDMERS J, BUKAU B AND MOGK A. 2012a. Chaperone networks in protein disaggregation and prion propagation. J Struct Biol 179: 152-160.

WINKLER J, TYEDMERS J, BUKAU B AND MOGK A. 2012b. Hsp70 targets Hsp100 chaperones to substrates for protein disaggregation and prion fragmentation. J Cell Biol 198: 387-404.

Wolfe KJ, REN HY, TREPTE P AND CYR DM. 2013. The Hsp70/90 cochaperone, Sti1, suppresses proteotoxicity by regulating spatial quality control of amyloid-like proteins. Mol Biol Cell 24: 3588-3602.

WOlfe KJ, REN HY, TREPTE P AND CYR DM. 2014. Polyglutamine-rich suppressors of huntingtin toxicity act upstream of Hsp70 and Sti1 in spatial quality control of amyloid-like proteins. PloS One 9: e95914.

XU LQ ET AL. 2013. Influence of specific HSP70 domains on fibril formation of the yeast prion protein Ure2. Philos Trans R Soc Lond B Biol Sci 368: 20110410.

YAMAGISHI N, YOKOTA M, YASUDA K, SAITO Y, NAGATA K AND HATAYAMA T. 2011. Characterization of stress sensitivity and chaperone activity of Hsp105 in mammalian cells. Biochem Biophys Res Commun 409: 90-95.

ZIETKIEWICZ S, KRZEWSKA J AND LIBEREK K. 2004. Successive and synergistic action of the Hsp70 and Hsp 100 chaperones in protein disaggregation. J Biol Chem 279: 44376-44383.

ZIETKIEWICZ S, LEWANDOWSKA A, STOCKI P AND LIBEREK K. 2006. Hsp70 chaperone machine remodels protein aggregates at the initial step of Hsp70-Hsp100-dependent disaggregation. J Biol Chem 281: 7022-7029. 
ZOLKIEWSKI M. 2006. A camel passes through the eye of a needle: protein unfolding activity of Clp ATPases. Mol Microbiol 61: 1094-1100.
ZOLKIEWSKI M, ZHANG T AND NAGY AM. 2012. Aggregate reactivation mediated by the Hsp 100 chaperones. Biochem Biophys 520: 1-6. 